\title{
VIDEO MATERIALS AS A MEANS OF PROMOTION AND ADVERTISING OF THE FIELDS OF STUDY
}

\author{
Mirosław Malec ${ }^{1}$, Tomasz Cieplak², Łukasz Jarmuł ${ }^{3}$ \\ 1 Faculty of Fundamentals of Technology, Lublin University of Technology, Nadbystrzycka 38, 20-618 Lublin, \\ Poland, e-mail:m.malec@pollub.pl \\ 2 Department of Enterprise Organization, Faculty of Management, Lublin University of Technology, \\ Nadbystrzycka 36, 20-618 Lublin, Poland, e-mail: t.cieplak@pollub.pl \\ ${ }^{3}$ Student of Lublin University of Technology (Technical and Information Education field of study), Nadbys- \\ trzycka 38, 20-618 Lublin, Poland
}

Received: 2016.06 .04

Accepted: 2016.07.05

Published: 2016.09.01

\begin{abstract}
In this paper there were presented some information about marketing and advertisement in the aspect of acquiring customers-candidate for studies with the help of the film as a tool of this kind of action. The paper also shows the results of the survey research and their analysis in the scope of expected features which will be characteristic, according to the respondents, for above-mentioned transfer tool.
\end{abstract}

Keywords: marketing, advertisement, film for promotion, candidate for studies, survey research.

\section{INTRODUCTION}

In a nutshell marketing is managing cordial relationship with a client. It involves attracting new customers via the promise of higher value and maintaining their positive outlook on sold products or services. As stated by $\mathrm{Ph}$. Kolter "Marketing is an integrated set of tools and actions which involve researching a market and shaping it, and which are based on market rules of conduct". Contemporary world is dependent on marketing. Marketing campaigns are one of the most noticeable and spectacular activities of business organizations and other institutions. Higher education facilities take advantage of marketing in order to promote their educational offer. When selecting a faculty a prospective student makes a groundbreaking decision that affects the path in life he will pursue. It is at this point that college or university ought to direct such candidate to its offer. Two marketing approaches prove particularly effective in this scenario: direct marketing and interactive marketing. [13]
According to American Direct Marketing Association direct marketing can be defined as "a system of marketing activities which involves at least one kind of media and which aim to provoke a measurable reaction, leading to successful transaction in any place, at any time". As such it can be used for recruitment purposes when the university employee has achieved direct contact with the candidate. One such opportunity are Open Day events, when prospective students can enter into direct contact with university employees. However, this form of advertising requires specialist training of the personnel. Not only does it involve technical aspects of presentation, but also the way the employees communicate with the client, their ability to observe the client's interests, their use of convincing argumentation and the form of conversation. Inappropriate conversation, strident attitude, inability to answer questions and specialized queries may dissuade the candidate from enrolling on this particular facility of higher education. 
Interactive marketing can be defined as marketing methods and tools dependent on data carriers and data channels, especially the Internet. It involves fast and semi-direct promotion of the offer to its target demographic. An university website would be the perfect example of this approach. It enables users to find all the necessary information quickly and efficiently. The general look and layout of the site should encourage the user to stay and browse the facility's offer. As a result the candidate may decide to enroll on particular faculty. Film and associated video materials are another means of interactive marketing, which may constitute a perfect tool for promotion of a university. It creates an opportunity to address the target demographic directly. This leads the authors of this paper to the following claim: that Internet and video materials combined together constitute a crucial means of interactive marketing.

\section{A PROSPECTIVE STUDENT - THE OVERVIEW OF THE CLIENT}

A client can be defined as a buyer or consumer. This term describes all participants in the market that take advantage of the goods and services available therein. It applies either to one physical entity or an organization made up of such individuals. A client is one of the market's mainstays and as such market could not exist without clients. Clients create demand which is satisfied by providers. In effect, clients enjoy a certain degree of privileged position in comparison with providers as it's their demands that require saturation in the best way possible. [15] A prospective student is also a form of a client, whose demands are satisfied by the facilities of higher education. However, in order to reach target demographic their personality must be carefully evaluated which is of paramount importance when choosing a career path. Personality may be understood as "inner structure of a person whose knowledge, experience and attitudes intertwine in a harmonious manner." In summary, personality is an exceptional trait because it results from acquired knowledge and experience as well as inherited characteristics. It is impacted by age, gender, income and family situation. It is important to remember that personality changes as individuals age and can be defined by one or several traits. Depending on those traits consumers can be divided into following categories:

- the conservatists: are adverse to experimentation when faced with the choice of a product of service,

- the tenacious: they "fight", they are determined, they want to achieve their goals through their choice of a good or service,

- the copycats: they tend to observe other consumers and base their decisions on these observations,

- the high achievers: they live affluent lives and as such they are considered a model to follow by other consumers,

- the thrill seekers: they want to experience as many things as possible and are open-minded to any offers made by the providers [5].

Getting to know an individual's personality enables providers to reach him more easily, and thus more easily convince him to take advantage of our services. Unfortunately, it is exceptionally difficult to identify personality type of target candidate demographic when preparing an advertisement. For this reason, the above-mentioned categories must be accounted for during development of promotional materials so that the commercial attracts the widest possible range of audience. Having summarized consumer types, the next step would be focusing more on the candidate - a prospective student himself. According to literature data and empirical evidence of the authors the following premises may factor in the decision of enrollment to particular field of study:

- wish to continue education

- possibility to continue education abroad

- self-realization,

- improving one's skills; fulfilling one's passion and interests,

- wish to obtain higher degree,

- possibility of finding better employment,

- family situation,

- peer influence.

The selected premises mentioned above do not exhaust all the aspects of this problem, but all the same it is worth giving them exceptional attention prior to making an offer and conducting promotional activities catering for prospective students.

An advertisement is a type of persuasive communication which comprises techniques and actions that draw consumer's attention to a product, idea or service. This form of presentation ac- 
counts for phenomena that take place on the market, most importantly including motives, ways of conduct and attitudes of consumers who make informed decisions about goods and services. It's fundamental role is to present information about goods and about ways they can be purchased. Contemporary advertisements fulfill also other functions, such as: presentation, foundation and maintenance of market outlets as well as shaping the demand. Advertisements can take advantage of many visual forms of expression such as: albums, posters, movies, television, newspaper notices etc. Audio-acoustic means of advertising such as, radio, mobile phone advertising also enjoy substantial popularity. Advertising has become commonplace especially in advanced countries. The goal of advertisements is to convince its audience about the merits of offered services and goods. The provider attempts to frame information about the product in such a way so that he can attract consumers, building up the desire to obtain the item in question and finally to finalize the transaction [16]. Advertising may also enhances brand loyalty of already established consumer base. It influences the perception of the product by the consumers who already purchased it, which by means of the word of mouth can impact the image of the product in potential new buyers. It also can be purely informative providing users with news about working hours of the company or any changes that are about to take place. Moreover, advertising aids the given company in struggles against competition by persuading the consumers to shift their attitude towards manufactured products and contextualize it against products made by other companies. As a result, advertisements frequently contain extra information about additional benefits of the given service or good, or ability to improve the given service or good in some way. Another function of advertising is promoting products that are just entering the market. To this end the company informs about the new good or service its purpose, features - all in order to draw consumer's attention. Advertisements may be subdivided into many categories depending on certain criteria. First and foremost, depending on the desired outcome of advertisement we differentiate as follows: pioneering advertising, competitive advertising and reminder advertising. Second, depending on the physical means of reaching target demographic we may define: ATL (above the line) advertisements and BTL (below the line) advertisements. Third, depending the senses that are affected by an advertisement we identify: visual, acoustic, audio-visual and olfactory advertisements. All of the abovestated categories comprise larger part of the whole since it is difficult to prepare an effective advertising campaign relying on just one type of commercials. At the present in order to reach the largest possible audience different type of advertisements should be used in concert. However the choice of advertising category must be complimented by the choice of appropriate advertising carrier. This is conditioned by the type of the advertised product and the given market's specification. For this purpose the following types of mass media are taken advantage of: newspapers, television, radio and Internet. However, of these it is the Internet that presents the greatest potential. Its primary advantage is virtually unlimited geographic reach, which in itself poses also a considerable challenge - the advertised product must stand out in order to be noticed from among thousands of websites. A large number of advertisements in the Internet resulted in growing indifference towards them. For this reason an Internet advertisement is most commonly directed towards younger people who constitute its largest user demographic. Effectiveness of advertising is reflected in an increase of interest and sales of a good or service. Thus an effective advertisement will be one that fulfills the following criteria: it builds brand recognition, it promotes brand loyalty, it creates strong arguments in favor of the product when compared with alternatives offered by the competition, it educates consumers, it improves reputation and it creates positive outlook on the company's services. In time, a successful campaign based on these criteria is bound to be more cost-effective than convincing consumer to make a one-time purchase. That is why developing brand recognition and improving reputation, which leads to greater brand loyalty, and in turn to greater resistance against competition, is of paramount importance. If we additionally take care of good business image, entering and maintaining relationship with consumers, and in case of higher educational facilities, prospective students, should prove relatively easy. In summary, any advertisement that realizes its goal to the highest extent can be deemed effective. However, maintaining consumer's positive image of company or institution on both rational and emotional levels is more important than fulfilling one-time goal. 
When producing advertisements of schools one should take into consideration the method of addressing the target audience. The way of communicating the information with them is of particular importance. For this reason it is necessary to familiarize oneself with aspects of social interaction, which constitutes the cornerstone of every advertisement. Technical considerations ought to also be taken into account, especially those that impact visual facets of the project. Communication in social interactions can be defined as a process of gathering, altering and passing information between individuals, groups and social institutions. As such it dynamically shapes knowledge, behavioral patterns and attitudes according to the interests and values of the subjects that are affecting it. In the course of social interaction via multimedia the sender takes advantage of means of persuasion and manipulation with the ultimate goal of provoking certain reaction of the recipient. We can distinguish multiple layers of social interaction depending on certain criteria: means of communication: verbal, non-verbal, symbolic; the distance between sender and receiver - indirect and direct; level of communication - intrapersonal, interpersonal, group, institutional and mass communication. Within the frame of multimedia projects mass communication, marketing and communication through computer are especially important. Mass communication is technologically demanding. It is characterized by asymmetrical relationship between both sides and being limited to one-way direction. In such scenario an institution is the sender, whereas target demographic constitutes the group of recipients, whose impact on the sender is reduced to a minimum. The means of mass communication may be used as a modern form of one-way interaction and as a public forum. Mass-media certainly affect the decision making process of future university candidates. It is owing to mass communication that desired information can be passed on to a large audience via, e.g. the Internet. Marketing communication conditions the state of any given company. It can be defined as a way in which that institution transmits its knowledge about the organization itself, its products and services to potential clients as a promotion or advertisement. Dialog is cornerstone in this type of communication. Based on the quality of dialog the client may form his own vision of company which thus he may deem worthy of his loyalty. Such a client will gladly take advantage of goods and services of- fered to him. Computer as a means of communication relies on digitally formatted data which is transferred through phone-line or other telecommunication link such as cable or satellite. This term encompasses all means of digital communication, from rudimentary ones such as email to internet forums and live chat. Another paramount facet of promoting services is inside-out command of public relations. According to German PR Association, Public Relations (PR for short) can defined as "the management of communication processes between organization and individuals through sets of benchmarks which enable deliberate, purposeful and systematic defining of those processes." As all methods of communication, the approach to PR depends on business activity conducted by the institution. However, there are some common denominators: contact with the press - presenting news and revelations concerning products and services in the best light; product publicity - improving product's visibility and popularity; communication - popularizing the correct understanding of company's mission and activities; lobbying - maintaining contact with legislators and state officials in order to be able to persuade them to particular policies; consulting counseling the chief company's officers in public matters and the organization's position in the time of crisis and good economic standing alike [6].

The above-mentioned elements of PR enable the institution to formulate the following strategic goals:

- building positive attitudes towards the organization, its activities, values and goals,

- shaping desirable public image, reputation and consumer opinions,

- gaining, regaining and maintaining trust,

- decreasing the discrepancy between the factual state of the institution and public impressions as well as expectations through balancing interests.

- limiting or removing potential conflicts, enhancing organization's capabilities in the time of crisis,

- enabling clients and company to reach a consensus,

- positioning the institution in the awareness of general population [12].

E-public relations is a particular form of PR that warrants further scrutiny as its based around the Internet. Internet advertising grounded in an attractive promotional instruments may prove 
very successful at convincing prospective university students. A website is one such good example of a promotional tool. Thanks to it the client can decide on his own what he wants to see and what he wants to focus on. A website is a form of business card and an advertisement as well as the first step before familiarizing with the facility's offer. Visual cues and multimedia are the major modes interactivity on a website. In order that the information can reach the client and be memorized it must be interesting, attractive, and advantageous to the consumer. It is possible to differentiate two types of behaviour in the Internet: need-based and interest-based. The former describes the type of behaviour where certain information is necessary for the client and he knows how to fulfill this demand, for instance, through a website where he can find the information he needs. The latter case involves seemingly aimless browsing the website, where the user activates banners, links and follows entries which catch his attention. This group may be reached through an attractive, up-to-date website. For this reason the website should contain not only textual content concerning the type of studies, but also videos promoting the facility or the particular faculty [12].

\section{SURVEY RESEARCH AND ITS RESULTS}

The survey devised for this research comprised six questions that were directed to future candidates and currents students at university. Its purpose was to designate the best means of promoting the Technical and Information Education field of study at Lublin University of Technology and finding out what characteristics of this medium are more desirable.

The respondents were asked the following questions:

Query 1.

What type of advertisement attracts you the most?
a) textual content,
b) illustrations,
c) video.

\section{Query 2.}

When making the decision about the future field of study you will rely on...

a) textual information,

b) photographs illustrating the field of study,

c) promotional video presenting the field of study.
Query 3.

In the case of a video which promotes a field of study, how long one should be?

a) 1-3 min.,

b) 3-6 min.,

c) over $6 \mathrm{~min}$,

d) videos are not optimal to promote a field of study.

Query 4.

The promoting film should contain...

a) a slideshow,

b) movie takes,

c) movie takes + slideshow,

d) videos are not optimal to promote a field of study.

\section{Query 5.}

How should the information be presented in a promotional video?

a) via textual commentary and subtitles,

b) via voice commentary,

c) video without commentary,

d) videos are not optimal to promote a field of study.

\section{Query 6.}

Does the background music and sound in an advertisement catch your attention?
a) yes,
b) no,
c) no opinion.

The survey research was based on the research sample of 126 people. The respondents were divided into three groups. The first group consisted of future candidates - the graduates of August Zamoyski's Agricultural School Complex in Jabłoń. It was made up of 30 graduates. The survey results gathered from this group can be found in table 1. Respective cells in the first column contain numbers of each survey query. The remaining columns present the number of answer given to each option.

Table 1. The answers of high school graduates

\begin{tabular}{|c|c|c|c|c|}
\hline \multicolumn{6}{|c|}{ High school graduates } \\
\hline Q/A & a & b & c & d \\
\hline 1 & - & 10 & 20 & - \\
\hline 2 & 6 & 8 & 16 & - \\
\hline 3 & 7 & 13 & 10 & - \\
\hline 4 & 2 & 8 & 20 & - \\
\hline 5 & 1 & 25 & 4 & - \\
\hline 6 & 30 & - & - & - \\
\hline
\end{tabular}


The next group comprised full-time second year students in the field of Technical and Information Education at Lublin University of Technology. Fifty seven students participated in this survey. Its results are presented in Table 2.

The final group was made up of, 3rd year graduate students in the field of Technical and Information Education. Thirty nine students provided answers to the queries. The results for this survey were are showcased in Table 3, whereas the consolidated results can be found in Table 4.

Table 2. The answers given by full-time second year students in the field of Technical and Information Education

\begin{tabular}{|c|c|c|c|c|}
\hline \multicolumn{6}{|c|}{ 2nd year TIE students } \\
\hline Q/A & a & b & c & d \\
\hline 1 & 6 & 21 & 30 & - \\
\hline 2 & 21 & 14 & $\mathbf{2 2}$ & - \\
\hline 3 & 25 & $\mathbf{3 0}$ & 2 & - \\
\hline 4 & 6 & 16 & 35 & - \\
\hline 5 & 11 & $\mathbf{4 3}$ & 2 & 1 \\
\hline 6 & $\mathbf{4 9}$ & 4 & 4 & - \\
\hline
\end{tabular}

Table 3. The answers given by full-time third year graduate students in the field of Technical and Information Education

\begin{tabular}{|c|c|c|c|c|}
\hline \multicolumn{6}{|c|}{ 3rd year TIE students } \\
\hline Q/A & a & b & c & d \\
\hline 1 & 1 & 9 & $\mathbf{2 9}$ & - \\
\hline 2 & 15 & 5 & 19 & - \\
\hline 3 & 11 & $\mathbf{2 2}$ & - & 1 \\
\hline 4 & 1 & 9 & $\mathbf{2 8}$ & 1 \\
\hline 5 & 5 & $\mathbf{3 2}$ & 2 & 1 \\
\hline 6 & $\mathbf{3 4}$ & 1 & 4 & - \\
\hline
\end{tabular}

Table 4. Consolidated answers

\begin{tabular}{|c|c|c|c|c|}
\hline \multicolumn{6}{|c|}{ Consolidated answers } \\
\hline Q/A & a & b & c & d \\
\hline 1 & 7 & 40 & 79 & 0 \\
\hline 2 & 42 & 27 & 57 & 0 \\
\hline 3 & 43 & 65 & 12 & 1 \\
\hline 4 & 9 & 33 & 83 & 1 \\
\hline 5 & 17 & 100 & 8 & 2 \\
\hline 6 & 112 & 5 & 8 & 0 \\
\hline
\end{tabular}

\section{SUMMARY AND CONCLUSIONS}

The first query received $\mathrm{c}$ as the most frequent answer - it was selected by 79 respondents. Thus it can be concluded that video advertisements enjoy the greatest degree of impact of all the available options. The respondents also chose videos as the preferred medium of promoting studies, with 57 of them selecting option "c" in the second query. Sixty nine respondents opted from answer " $b$ " for the third query. This suggests that and ideal promotional video should be 3-6 minutes long. "C" was the prevalent response for query 4 given by 83 respondents. According to them video materials promoting a field of study should consist of both movie takes and slideshows. Furthermore, "b" was the most popular answer to the fifth query as confirmed by 100 respondents. It is thus expected that all the information should be conveyed through voice commentary. As for the last question the most answers were given to option "a" by 113 respondents. This confirmed that a video promoting a field of study should include an appropriate and atmospheric music score in the background.

The analysis of premises associated with marketing, social interaction, survey research as well as practical use of multimedia project which promotes the field of study in Technical and Information Education lead to following conclusions:

1. According to the authors of this paper, using appropriately adjusted element - advertising and the way it is conveyed to the client, is one of the crucial means of promotion. For this reason, it is paramount to learn techniques and marketing trends that can be taken advantage of for the purpose of promoting services and institutions, and in the abovesaid scenario, a field of study.

2. Learning aspects of social interactions improves effectiveness and reach of promotional campaigns. Utilizing video as the communication carrier allows for attracting new clients more efficiently.

3. Learning the needs of the target demographic is crucial in order to make the video that could address it. Among many other, survey research proves to be one of the most efficient tools of achieving that. In the presented scenario, project objectives were formulated on the basis of achieved results and their analysis 
as well as their conclusions. These objectives laid the groundwork for multimedia project a video promoting Technical and Information Education as a field of study.

\section{REFERENCES}

1. Armstrong G., Kotler P., Marketing wprowadzenie. WKP Warszawa 2012.

2. Domańska K., Czas marketingu bezpośredniego. „Marketing w praktyce”, nr 3, 2007.

3. Domański T., Skuteczna reklama i promocja. Poltext Warszawa 1993.

4. Kotra K., Pysz-Radziszewska A., Marketing w teorii i praktyce. WSB Poznań 2001.

5. Michalski E., Marketing podręcznik akademicki. PWN Warszawa 2004.

6. Olvier S., Strategia Public Relations. PWE Warszawa 2005.

7. Podgórski R.A., Metodologia badań socjologicz- nych, Branta, Bydgoszcz - Olsztyn 2007.

8. Rószkiewicz M., Perek-Białas J., WęziakBiałowolska D., Zięba-Pietrzak A., Projektowanie badań społeczno-ekonomicznych. PWN Warszawa 2013.

9. Sobotkiewicz D., Waniowski P., Marketing zagadnienia podstawowe. PLACET Warszawa 2006.

10. Śmid W., Leksykon komunikacji medialnej. Dr Lex Publishing House, Kraków 2010.

11. White R., Reklama, czyli co to jest i jak się ją robi. Business Press Ltd., Warszawa 1997.

12. Witek E., Komunikacja wizualna nowoczesne narzędzia. ASTRUM Wrocław.

13. Wojciechowski T., Encyklopedyczne podstawy marketingu. PLACET Warszawa 2009.

14. http://www.biznesklaster.pl/company/article/123rodzaje-reklamy-i-elementy-wpywajace-na-jejskutecznose/, 14.01.2015.

15. http://ksiazekreatywnosci.pl/kim-jest-klient/, 15.01.2015.

16. https://www.encyklopedia.pwn.pl, 10.01.2015. 